\title{
Bleaching of the coral Oculina patagonica by Vibrio AK-1
}

\author{
A. Kushmaro ${ }^{1}$, E. Rosenberg ${ }^{2}$, M. Fine ${ }^{1}$, Y. Loya ${ }^{1, *}$ \\ ${ }^{1}$ Department of Zoology and ${ }^{2}$ Department of Molecular Microbiology and Biotechnology, \\ Tel Aviv University, Ramat Aviv, Tel Aviv 69978, Israel
}

\begin{abstract}
Bleaching in stony corals is the result of a disruption of the symbiosis between the coral hosts and photosynthetic microalgal endosymbionts (zooxanthellae). Coral bleaching may be induced by a variety of environmental stimuli, including increased seawater temperature. Large-scale bleaching episodes have been suggested to be linked to global warming. We have díscovered that coral bleaching, in this case, bleaching of the Mediterranean coral Oculina patagonica, is caused by a bacterial infection and that water temperature is a contributing factor The causative agent, Vibrio AK-1. was present in 28 bleached $O$. patagonica examined, but absent from 24 healthy (unbleached) corals. The Vibrio sp. was isolated in pure culture, characterized microbiologically, and shown to cause bleaching when inoculated onto unbleached corals. An increase in seawater temperature may influence the outcome of bacterial infection by lowering the resistance of the coral to infection and/or increasing the virulence of the bacterium. When inoculated with $10^{6}$ Vibrio $\mathrm{AK}-1 \mathrm{ml}^{-1}$ at $26^{\circ} \mathrm{C}$, bleaching began at around $10 \mathrm{~d}$ and affected more than $80 \%$ of the corals after $44 \mathrm{~d}$. Bleaching did not occur under the same conditions in the presence of antibiotics or if the temperature was lowered to $16^{\circ} \mathrm{C}$
\end{abstract}

KEY WORDS: Coral - Bleaching · Bacterial infection - Vibrio - Oculina - Mediterranean

\section{INTRODUCTION}

Coral bleaching, the disruption of symbioses between corals and microalgae (zooxanthellae; Brown et al. 1995), is a problem that threatens coral reefs throughout the world. Coral bleaching events of unprecedented frequency and global extent were reported in the 1980s and early 1990s (Goreau 1990, Glynn 1991a, Hoegh-Guldberg \& Salvat 1995). The subject is of concern because of mortality and local extinctions associated with large-scale bleaching episodes (Glynn 1991b), the fact that bleaching episodes have increased dramatically in frequency and intensity within the past decade (D'Elia et al. 1991), and speculation about possible links to global warming (Jokiel \& Coles 1990, Glynn 1991b, 1993, Smith \& Buddemeier 1992, Buddemeier \& Fautin 1993). A number of causes have been suggested for bleaching, including elevated temperatures (Jokiel \& Coles 1977, 1990. Gates 1990, Glynn 1990, Glynn \& D'Croz 1990, Gates

\footnotetext{
- Addressee for correspondence.

E-mail: yosiloya@ccsg.tau.ac.il
}

et al. 1992, Fitt \& Warner 1995) and increased irradiance (Glynn et al. 1992, Gleason \& Wellington 1993, Shick et al. 1995).

Buddemeier \& Fautin (1993) have suggested that coral bleaching is a normal regulatory process by which genetic variation among the zooxanthellae is allowed. Bleached coral reefs generally have a patchy appearance due to the irregular distribution of bleached colonies (Glynn et al. 1985). Edmunds (1994) suggested that the reef-wide spatial distribution of bleached coral colonies is the result of the distribution of bleachingsusceptible clonal genotypes. Despite these efforts, little progress has been made in understanding why some corals bleach while others do not (Edmunds 1994).

Although bacteria are known to be abundant and active around corals and in the coral surface microlayer (Sorokin 1973, Mitchell \& Chet 1975, Ducklow \& Mitchell 1979, Ritchie \& Smith 1994), little information exists on the structure, composition and maintenance of the bacterial community. The surface of living corals is covered by a mucoid material. This surface mucopolysaccharide layer provides a matrix for bacterial colonization, allowing for the establishment of a 'nor- 
mal bacterial community' which may be characteristic of a particular coral species (Mitchell \& Chet 1975 , Ducklow \& Mitchell 1979, Rublee et al. 1980, Segel \& Ducklow 1982, Ritchie et al. 1994)

Recently, Kushmaro et al. (1996) indicated that bleaching of the coral Oculina patagonica is caused by bacterial infection. $O$. patagonica was first observed in the Mediterranean in 1966 and was presumed to be an immigrant species accidentally introduced from South America (Zibrowius 1974). Recent surveys show that $O$. patagonica is abundant in wide areas along the Israeli coast of the Mediterranean at a depth range of 1 to $50 \mathrm{~m}$. Most of the bleached colonies have been found in patchy formations at depths of 1 to $6 \mathrm{~m}$. The number of bleached colonies increased rapidly from late May to September following rising sea temperatures reaching $29^{\circ} \mathrm{C}$ (Fine \& Loya 1995). Bleaching of $O$. patagonica was first observed in the summer of 1993 and since then has been continuously monitored. In this paper, we present data on the isolation and characterization of Vibrio AK-1 and on the ability of this bacterium to infect and cause bleaching of $O$. patagonica under laboratory conditions.

\section{MATERIALS AND METHODS}

Collection and maintenance of the corals. Intact colonies of the coral Oculina patagonica were collected during the summer of 1995 from a depth of 1 to $3 \mathrm{~m}$ at 3 sites along the Mediterranean coast of Israel (see Table 2). Seawater temperature at time of collection was 25 to $26^{\circ} \mathrm{C}$. Within 1 to $2 \mathrm{~h}$ of collection, each colony was split into several pieces and placed into $2 \mathrm{I}$ aerated aquaria containing filtered seawater $(0.45 \mu \mathrm{m})$ that were maintained at $25^{\circ} \mathrm{C}$. The aquaria were illu-

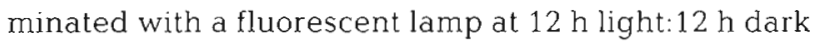
intervals. Coral pieces were allowed to recover and regenerate for $15 \mathrm{~d}$ before the start of each experiment. If any piece failed to heal (complete cover of damaged skeleton by new tissue), it was discarded and not used in any experiment.

Vibrio AK-1 sampling and isolation. Small pieces of bleached and unbleached corals collected as described above (in all, 28 samples were taken from bleached corals and 24 samples from unbleached corals) were placed in sterile tubes and brought to the laboratory within $2 \mathrm{~h}$. The mucous surface layer of each piece was removed with a sterile loop, diluted into sterile seawater, streaked onto Marine Agar (18 g Marine Broth, Difco MA 2216, $9 \mathrm{~g} \mathrm{NaCl}$ and $18 \mathrm{~g}$ Difco Bacto Agar, per 11 of deionized water) and incubated at $30^{\circ} \mathrm{C}$ for $3 \mathrm{~d}$. The dominant colony types were restreaked onto Marine Agar to obtain pure cultures. These strains were subsequently tested for their pathogenic effect on healthy Oculina patagonica. The only strain able to induce bleaching, referred to as $A K-1$, was subsequently characterized as belonging to the genus Vibrio (Farmer \& Hickman-Brenner 1992). The presence of strain Vibrio AK-1 was determined by its characteristic colony morphology, cellular morphological pattern and antibiotic sensitivity pattern.

Characterization of Vibrio AK-1. Strain Vibrio AK-1 was routinely cultivated on Marine Agar or Marine Broth at $30^{\circ} \mathrm{C}$. Gram reaction, cell morphology and motility were determined microscopically. Scanning electron microscopy was performed on healthy and bleached coral pieces as well as on pure cultures of Vibrio $\mathrm{AK}-1$. Biochemical tests (indole production, nitrate from nitrite, acidification of glucose, arginine dihydrolyase, oxidase, esculine hydrolysis, gelatinase and $\beta$ galactosidase) were performed by api-20 NE (micromethod tests for the identification of Gram-negative rods, Bio Merieüx SA, Marcy-Ietoile, France). The standard api-20 NE method was used except that the media were adjusted to $3 \% \mathrm{NaCl}$. Growth and acid production were measured on TCBS Agar (DifCo) which contains sucrose. Salt tolerance was determined in Nutrient broth (Difco) containing 0 to $12 \%$ NaCl. Sensitivity to antibiotics $(10 \mu \mathrm{g}$ ampicillin, $15 \mu \mathrm{g}$ erythromycin, $10 \mu \mathrm{g}$ penicillin-G, $30 \mu \mathrm{g}$ tetracycline, $30 \mu \mathrm{g}$ kanamycin and $10 \mathrm{\mu g}$ streptomycin, each applied to a paper disc) was determined after incubation for $24 \mathrm{~h}$ at $30^{\circ} \mathrm{C}$ on Marine Agar. Sensitivity to $30 \mu \mathrm{g}$ per disc of the Vibriospecific compound Vibriostatic 0129 (Sigma), was determined as described above. Vibriostatic 0129 is 2,4-diamino-6,7-diisopropylpteridine. This compound specifically inhibits the growth of bacteria of the genus Vibrio. Microbial fatty acid profile was analyzed using the MIDI/Hewlett Packard microbial identification system (Analytical Services Inc., Williston, VT, USA).

Laboratory bleaching experiments. Three types of experiments were performed. In the first set of experiments bleached and healthy corals were put together in 3 aerated $2 \mathrm{l}$ aquaria and maintained at 25 and $17^{\circ} \mathrm{C}$.

In the second set of experiments, $10 \mu \mathrm{l}$ containing $5 x$ $10^{6}$ cells $\mathrm{ml}^{-1}$ of Vibrio AK-1 were placed on each of 5 healthy corals and the corals were then put into separate aerated aquaria maintained at $25^{\circ} \mathrm{C}$. For a control, 5 corals were inoculated with $10 \mu$ of sterile medium rather than bacteria and placed in separate aquaria. To determine if the Vibrio AK-1 supernatant fluid was toxic to coral, a $24 \mathrm{~h}$ culture was centrifuged at $12000 \times g$ for $20 \mathrm{~min}$ and filtered through a $0.2 \mu \mathrm{m}$ membrane filter. The supernatant $(10 \mu l)$ was applied to corals as described above.

The third set of experiments was carried out without removing the corals from $2 \mathrm{l}$ aerated aquaria. In the first test, conducted at $26^{\circ} \mathrm{C}, 3$ aquaria, each containing 5 colonies of Oculina patagonica corals, were inoculated with Vibrio AK-1 to a final bacterial cell density 
of $5 \times 10^{6}$ cells $\mathrm{ml}^{-1}$. Two additional aquaria, each containing 6 colonies, served as controls. In the second test, 3 aquaria, each containing 6 colonies of $\mathrm{O}$. patagonica maintained at $16^{\circ} \mathrm{C}$ and $25^{\circ} \mathrm{C}$, were inoculated with Vibro AK-1 to a final bacterial cell density of $5 \times 10^{5}$ cells $\mathrm{ml}^{-1}$. For the antibiotic experiments, $100 \mathrm{mg} \mathrm{l}^{-1}$ of kanamycin and $100 \mathrm{mg} \mathrm{l}^{-1}$ of penicillin-G) were added to 1 infected aquarium. A control aquarium was treated in exactly the same manner except that it was inoculated with sterile medium in place of bacteria.

Determination of bleaching and histology. Percentage of bleaching was determined qualitatively by visual observation of corals in the laboratory and the field. Quantitative measurements were obtained by counting the number of algae directly from histological sections of bleached and unbleached coral tissue samples. Coral tissue samples were fixed in $4 \%$ formaldehyde solution in seawater for $24 \mathrm{~h}$, rinsed in fresh water and transferred to $70 \%$ ethanol for preservation. Decalcification was carried out using a solution of $1: 1(\mathrm{v}: \mathrm{v})$ formic acid (initial conc. $42.5 \%$ ) and sodium citrate (initial conc. $20 \%$ ) for 24 h. After decalcification, the tissue was rinsed in water and transferred to $70 \%$ ethanol. The dehydrated tissue was embedded in paraffin. Sequential cross-sections of the tissue were mounted on glass slides, and were stained with hematoxylin and eosin. These histological sections were examined through a Nikon light microscope at a magnification of $1000 x$ using a calibrated eye piece micrometer.

\section{RESULTS}

\section{Isolation and characterization of Vibrio AK-1}

During a survey of bacteria present in the mucus of different species of corals, we observed that there was a unique colony type associated with bleached Oculina patagonica. This bacterium, referred to as strain AK-1, was isolated in pure culture by dilution of a mucus sample from a bleached coral in sterile seawater, streaking onto Marine Agar and incubation at $30^{\circ} \mathrm{C}$ for $3 \mathrm{~d}$. Under these conditions, strain $\mathrm{AK}-1$ yielded characteristic cream-colored colonies. The strain was further purified by cloning onto Marine Agar.

The characteristics of strain AK-1 are summarized in Table 1. It is a Gram-negative, motile, rod-shaped bac-
Table 1. Characteristics of Vibrio sp. strain AK-1

Result
Cream colored, $5 \mathrm{~mm}$ diameter after $3 \mathrm{~d}$
Yellow, $5 \mathrm{~mm}$ diameter after $3 \mathrm{~d}$
Rod, $1.1 \times 0.5 \mathrm{~mm}$
Negative
Positive
Polar
Negative
Positive

-
+
+
+
+
+
-
+
+

Cream colored, $5 \mathrm{~mm}$ diameter after $3 \mathrm{~d}$ Negative

Negative

Positive

nenicillin- $G$, tetracycline, kanamycin Sensitive to ampic
and streptomycin

terium that contains a polar flagellum (Fig. 1a). These properties, together with its ability to form yellow colonies on TCBS Agar and its sensitivity to Vibriostatic 0129, define strain AK-1 as a marine species of the genus Vibrio (Farmer \& Hickman-Brenner 1992). Based on the antibiotic sensitivities, biochemical tests and carbon compound utilization, as well as the fatty acid profile (data not shown), strain AK-1 appears to be a new species of Vibrio.

\section{Distribution of Vibrio AK-1 on Oculina patagonica}

The initial observation that led us to consider the role of Vibrio AK-1 in bleaching of the coral Oculina patagonica was the presence of large aggregates of rodshaped bacteria on the border between bleached and unbleached zones at the tentacular rim (Kushmaro et al. 1996). These bacteria were also seen surrounding released zooxanthellae on the surface of bleached corals (Fig. 1b). No bacterial aggregates were seen on unbleached tissues.

During summer 1995 a systematic microbiological examination of bleached and unbleached coral colonies was performed at 3 sites on the Mediterranean coast of Israel. At Tel Aviv and Hedera, about $90 \%$ of the coral populations were bleached. The coral population at Achziv showed no sign of bleaching. Vibrio AK-1 were isolated from all 28 samples taken from bleached corals and were absent from all 24 samples taken from unbleached corals (Table 2) 

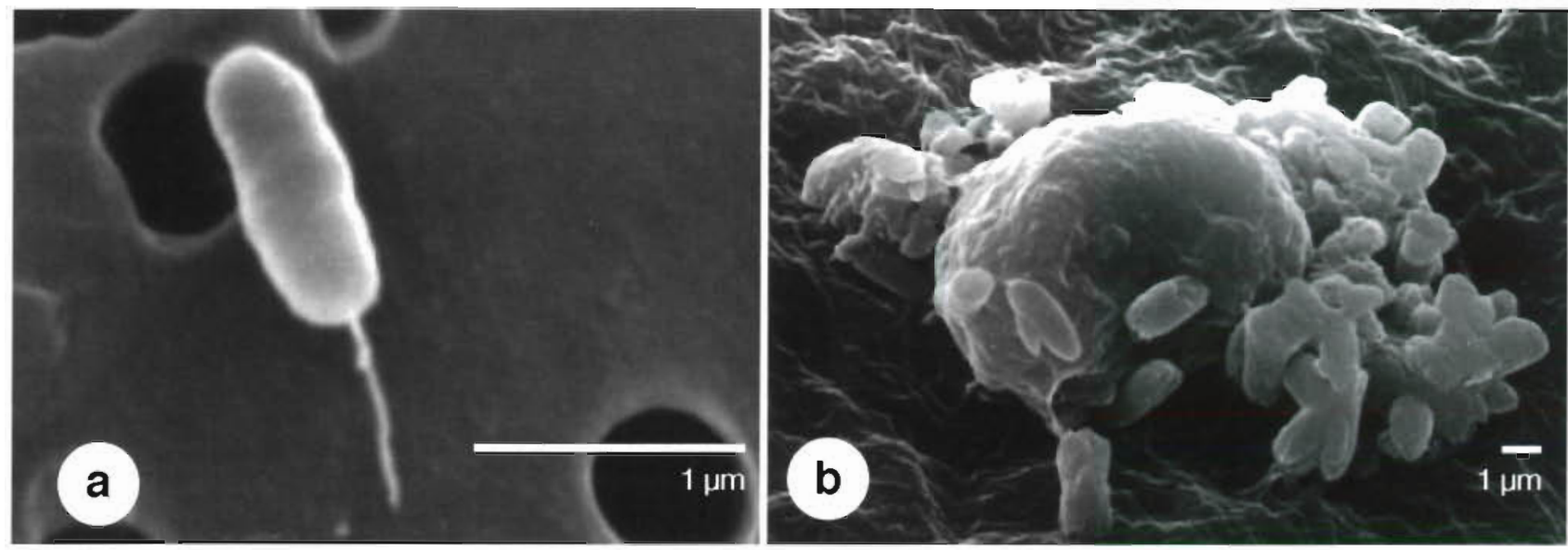

Fig. 1.Vibrio AK-1 and Oculina patagonica. Scanning electron micrograph of (a) Vibrio AK-1 with polar flagella, and (b) rodshaped bacteria surrounding a zooxanthellae on the surface of coral $O$. patagonica. Scale bar $=1 \mu \mathrm{m}$

\section{Induction of bleaching of healthy Oculina patagonica by bleached corals}

To test if there was a transmissible bleaching agent (first set of experiments), bleached and healthy corals were put together in aerated 21 aquaria and maintained at 25 and $17^{\circ} \mathrm{C}$. At $25^{\circ} \mathrm{C}$, all the healthy corals showed observable bleaching after $20 \mathrm{~d}$. Bleaching was not observed in the healthy corals at $17^{\circ} \mathrm{C}$. Furthermore, at $17^{\circ} \mathrm{C}$, the bleached corals began to show signs of recovery

\section{Infection of Oculina patagonica with Vibrio AK-1 in aquaria}

Two types of laboratory infection experiments were performed that demonstrate that pure cultures of Vibrio AK-1 infect Oculina patagonica and cause bleaching. In the second set of experiments, $10 \mu \mathrm{l}$ of resuspended cells of Vibrio AK-1 $\left(5 \times 10^{6} \mathrm{ml}^{-1}\right)$ were placed onto each of 5 healthy corals, and then the corals were put into separate aerated $2 \mathrm{l}$ aquaria maintained at $25^{\circ} \mathrm{C}$. All the corals showed bleaching at the site of inoculation after 6 to $8 \mathrm{~d}$. In a control experiment, in which $10 \mu \mathrm{l}$ of sterile medium was used in place of bacteria, no bleaching was observed even after $40 \mathrm{~d}$. Bleaching was due to the bacterial cells, not an extracellular metabolite, because filtration of the Vibrio AK-1 culture through a $0.2 \mu \mathrm{m}$ membrane filter led to an inactive cell-free supernatant.

In the third set of experiments, Vibrio $\mathrm{AK}-1$ was inoculated into the water of 21 aerated aquaria containing the corals Corals were not removed from aquaria for this procedure. In the first test, conducted at $26^{\circ} \mathrm{C}, 3$ aquaria were infected with $5 \times 10^{6}$ Vibrio AK-1 cells $\mathrm{ml}^{-1}$ and 2 additional agularia served as controls (Fig. 2). Iî̀ all 3 experimental aquaria there was observable bleaching after $10 \mathrm{~d}$, which by $44 \mathrm{~d}$ had spread over most of the corals. Tissue retraction was observed after $52 \mathrm{~d}$, followed by the death of the colonies within a few days. The corals in the control aquaria (no added bacteria) remained healthy for $52 \mathrm{~d}$, at which time the test was concluded. A visual comparison of an infected and a control coral is presented in Fig. 3

Vibrio AK-1 was also able to cause bleaching when inoculated at a density of $5 \times 10^{5}$ cells $\mathrm{ml}^{-1}$ into aquaria maintained at $25^{\circ} \mathrm{C}$. Each aquarium contained $6 \mathrm{Ocu}$ lina patagonica corals and the experiment was carried out without removing the corals from $2 \mathrm{l}$ aerated aquaria. Bleaching was determined after $44 \mathrm{~d}$, qualitatively by visual observation and quantitatively by counting the number of algae directly from histological sections of bleached and unbleached tissue samples (Table 3). Bleaching was not observed (1) without addition of bacteria, (2) when the temperature of the

Table 2. Oculina patagonica. Sampling sites, coral condition and presence of Vibrio sp. strain AK-1 in bleached corals. Numbers in parentheses represent the number of corals examined microbiologically

\begin{tabular}{|lll|}
\hline Sampling site & Coral condition & Vibno AK-1 \\
\hline Achziv $\left(33^{\circ} 02^{\prime} \mathrm{N}, 35^{\circ}\right.$ 05' E) & Normal (5) & Absent in all \\
Tel Aviv $\left(32^{\circ} 02^{\prime} \mathrm{N}, 34^{\circ} 42^{\prime} \mathrm{E}\right)$ & Normal (12) & Absent in all \\
& $30-50 \%$ bleached (14) & Present in all \\
& $90 \%$ bleached (5) & Present in all \\
Hedera (32 $\left.25^{\prime} \mathrm{N}, 34^{\circ} 55^{\prime} \mathrm{E}\right)$ & Normal (7) & Absent in all \\
& $30-50 \%$ bleached (9) & Present in all \\
\hline
\end{tabular}




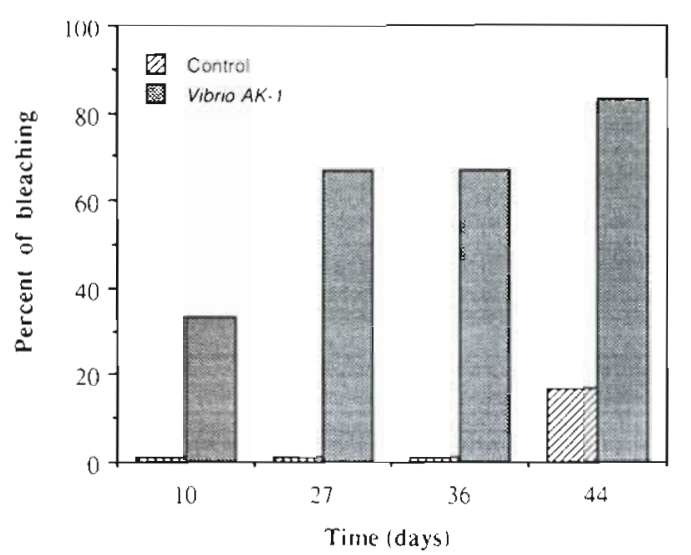

Fig. 2. Oculina patagonica. Percentage of bleaching due to Vibrio AK-1 infection at $26^{\circ} \mathrm{C}$. Five aquaria, each containing 6 $O$ patagonica corals, were maintained at $26^{\circ} \mathrm{C}$. Three of these aquaria were inoculated with Vibrio AK-1 at a bacterial cell density of $5 \times 10^{6} \mathrm{ml}^{-1}$. The 2 remaining control aquaria were treated in exactly the same manner except that they were inoculated with sterile medium in place of bacteria

aquaria was maintained at $16^{\circ} \mathrm{C}$, or (3) in the presence of $100 \mathrm{mg} \mathrm{l}^{-1}$ of kanamycin and $100 \mathrm{mg} \mathrm{l}^{-1}$ of penicillin$G$. The algae counts for the unbleached corals were similar in differing treatments (1.12 to $1.15 \times 10^{4} \mathrm{~mm}^{-2}$ ) and did not differ significantly (1-way ANOVA, $p>$ $0.05)$. After treatment with Vibrio AK-1 at $25^{\circ} \mathrm{C}$ for $44 \mathrm{~d}$, the algae counts decreased significantly (1-way ANOVA, $\mathrm{p}<0.001)$ in the 3 corals examined $(53,50$ and $37 \%$ ) compared to the average algae counts of the unbleached corals.

\section{DISCUSSION}

We showed that Vibrio AK-1 caused bleaching of Oculina patagonica at 25 and $26^{\circ} \mathrm{C}$, but not at $16^{\circ} \mathrm{C}$. This is consistent with the observation (Fine \& Loya 1995) that the bleaching occurs naturally in the summer, when seawater temperatures rise to an average of $26^{\circ} \mathrm{C}$ and reach a maximum of $29^{\circ} \mathrm{C}$, and recovery occurs during winter, when water temperature decreases to $16^{\circ} \mathrm{C}$.

Several authors have reported on the patchy spatial distribution and spreading nature of coral bleaching (Fisk \& Done 1985, Oliver 1985, Ogden \& Wicklund 1988, Glynn 1990, Jokiel \& Coles 1990, D'Elia et al. 1991, Hagman \& Gittings 1992, Lang et al. 1992, Edmunds 1994). It has been argued that the random mosaic patterns of bleaching observed in coral colonies is difficult to attribute solely to environmental stress, since neighboring regions of the colony must be exposed to the same extrinsic conditions (Hayes \& Bush 1990). The progression of observable changes that take place during coral bleaching are reminiscent of developing microbial biofilms on other biological tissues (Hoyle et al. 1993) or inorganic surfaces (Huang et al. 1995). Ritchie et al. (1994) demonstrated a shift in the structure of bacterial communities from Pseudomonas sp. to Vibrio sp. when Montastrea annularis became bleached. In the coral Oculina patagonica we demonstrated that Vibrio AK-1 appeared on all samples that were taken from bleached corals. Although we observed that bleaching was due to the bacterial cells themselves and not extracellular prod-
Fig. 3. Oculina patagonica Bleached coral 44 d after infection with $5 \times 10^{6}$ Vibrio AK-1 cells $\mathrm{ml}^{-1}$ at $26^{\circ} \mathrm{C}$ (left) and healthy coral (right). Magnification $4 \times$

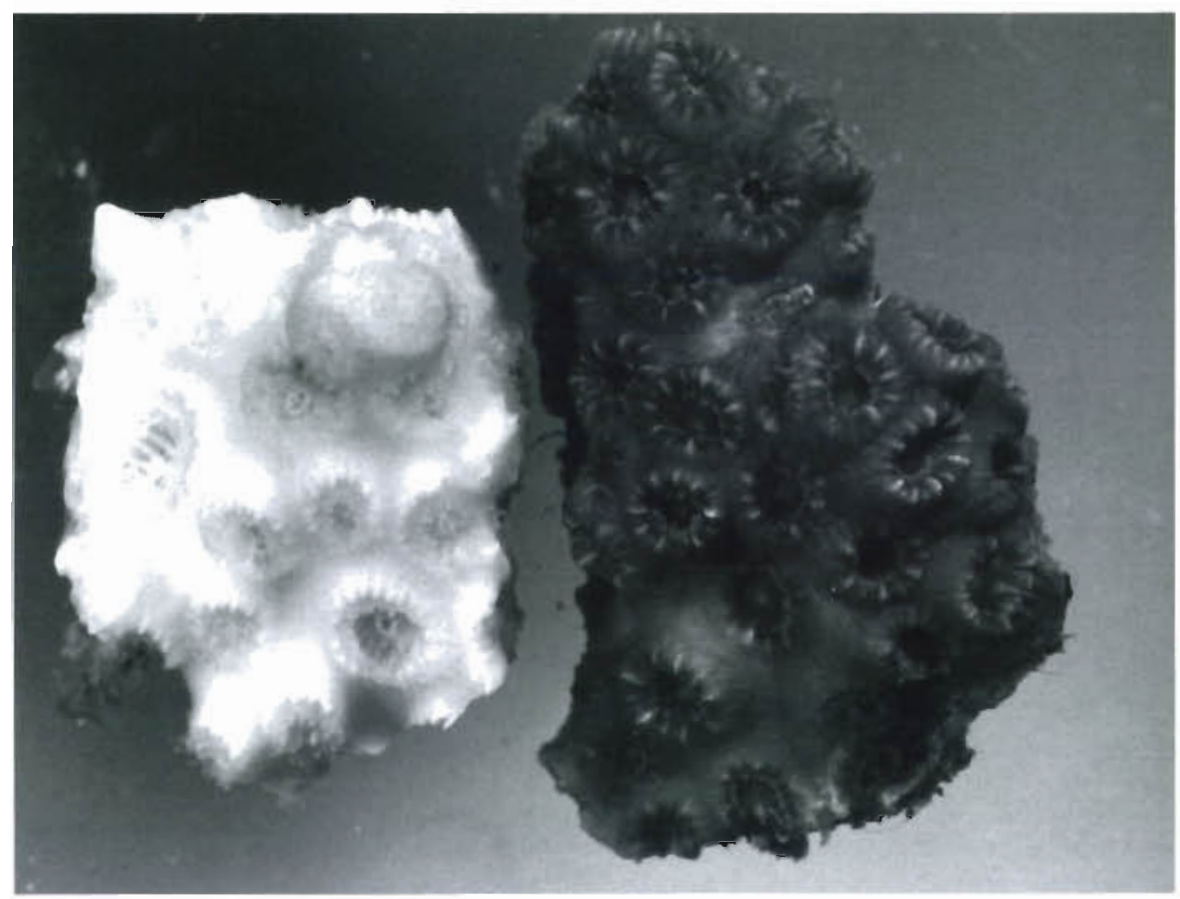


Table 3. Oculina patagonica. Infection with Vibrio AK-1 in aerated aquaria. Each aquarium contained 6 colonies. The algae counts represent the average \pm SE for 1 coral. Ten histological sequential cross-sections were analyzed for each coral

\begin{tabular}{|lcc|}
\hline Treatment & Visual observation & $\begin{array}{r}\text { Algae counts from } 1 \mathrm{~mm}{ }^{2} \\
\text { histological section }\left(\times 10^{4}\right)\end{array}$ \\
\hline $5 \times 10^{5}$ cells ml $^{-1}$ of Vibrio AK-1, $25^{\circ} \mathrm{C}$ & $90 \%$ bleaching & $0.54 \pm 0.03$ \\
& & $0.57 \pm 0.02$ \\
& & $0.72 \pm 0.02$ \\
$5 \times 10^{5} \mathrm{cells} \mathrm{ml}^{-1}$ of Vibrio AK-1, $16^{\circ} \mathrm{C}$ & No signs of bleaching & $1.13 \pm 0.04$ \\
$5 \times 10^{5} \mathrm{cells} \mathrm{ml}^{-1}$ of Vibrio AK-1, $25^{\circ} \mathrm{C}$, antibiotic & No signs of bleaching & $1.12 \pm 0.04$ \\
$\left(100 \mathrm{mg} \mathrm{l}^{-1}\right.$ of kanamycin and penicillin-G) & No signs of bleaching & $1.15 \pm 0.04$ \\
Control (no inoculum), $25^{\circ} \mathrm{C}$ & & \\
\hline
\end{tabular}

ucts in the supernatant, we propose that bleaching might be a result of extracellular toxins produced locally at the site of infection.

An early attempt to understand the mechanism for the bleaching on a Panamanian coral reef, coincident with the prolonged 1983 El-Niño warming event (Glynn et al. 1985), showed that normally colored colonies receiving bleached colony portions in grafts remained in a healthy state. In the gastrodermis of the bleached Pavona varians and Pocillopora elegans, colonies suspected of being bacteria were observed. Cryofractured samples of these tissues revealed the presence of spherical to rod-shaped bacteria-like objects in the gastrodermal cells, sometimes occupying zooxanthellae vacuoles, in both coral species (Glynn et aI. 1985). The authors concluded that thermal stress may be responsible for the coral deaths. However, it is difficult to exclude an infectious agent without knowing the mode of transmission or the minimum infectious dose. In acroporid corals afflicted with white band disease, Peters et al. (1983) discovered unusual, Gram-negative, rod-shaped bacteria living in aggregates in the calicoblast epidermis lining the gastrovascular canals. In our experiments we observed that the pathogenic bacteria on the bleached coral were highly concentrated at the borderline between the bleached and healthy tissue. Few bacteria were present over most of the bleached surface.

Buddemeier \& Fautin (1993) hypothesized that coral bleaching is a natural adaptive mechanism which provides an opportunity for the host coral to be repopulated with a different type of zooxanthellae. Stress conditions tend to favor coral-algae combinations which are resistant to the stress. In support of this hypothesis, it has been demonstrated that the same species of coral can form symbiotic relationships with different taxa of zooxanthellae (Rowan \& Knowlton 1995). We further suggest that the coral-algae combinations that would be selected are those that are resistant to bacterial infection. Coral bleaching followed by selection of new coral-algae combinations may be one of the mechan- ims by which Oculina patagonica develops resistance to Vibrio AK-1.

Our findings show that bleaching of the coral Oculina patagonica along the Mediterranean coast of Isracl is caused by a bacterial inlection. An increase in the temperature of seawater can influence the outcome of the bacterial infection in at least the following 2 ways: lowering the resistance of the coral to infection and/or increasing the virulence of the bacteriumi. The doubling times of Vibrio AK-1 in Marine Broth at 15 . 20,25 and $30^{\circ} \mathrm{C}$ were $240,95,60$, and $40 \mathrm{~min}$, respectively (authors' unpubl. data). The higher growth rate of Vibrio AK-1 at elevated temperatures may, at least in part, be responsible for the observed effect of temperature on coral bleaching

Acknowledgements. This work was supported by the United States-Israel Binational Science Foundation grant 95-00177. The Porter Super-Centre for Ecological and Environmental Studies and the Pasha Gol Chair for Applied Microbiology.

\section{LITERATURE CITED}

Brown BE, Le Tissier MDA, Bythell JC (1995) Mechanisms of bleaching reduced from histological studies of reef corals sampled during a natural bleaching event. Mar Biol 122 $655-663$

Buddemeier RW, Fautin DG (1993) Coral bleaching as an adaptive mechanism: a testable hypothesis. BioSci 43 : $320-325$

D'Elia CF, Buddemeier RW, Smith SV (1991) Workshop on coral bleaching, coral reef ecosystems and global change. Report of proceedings. June 1991, Maryland Sea Grant College, College Park, USA

Ducklow HW, Mitchell R (1979) Bacterial populations and adaptations in the mucus layers on living corals. Limnol Oceanogr 24:715-725

Edmunds PJ (1994) Evidence that reef-wide patterns of coral bleaching may be the result of the distribution of bleaching-susceptible clones. Mar Biol 121:137-142

Farmer JJ III, Hickman-Brenner FW (1992) The genera Vibrio and Photobacterium. In: Barlows A, Truper HG, Dworkin M. Harder W, Schleifer HK (eds) The prokaryotes, 2nd edn. Springer-Verlag, New York, p 2952-3011

Fine M, Loya $Y$ (1995) The hermatypic coral Oculina patago- 
nica, a new immigrant to the Mediterranean coast of Israel. Isr J Zool 41:84 (abstract)

Fisk DA, Done TJ (1985) Taxonomic and bathymetric patterns of bleaching in corals, Myrmidon Reef (Queensland). Proc 5th Int Coral Reefs Symp, Tahiti 6:149-154

Fitt WK, Warner ME (1995) Bleaching patterns of four species of Caribbean reef corals. Biol Bull (Woods Hole) 189 : $298-307$

Gates RD (1990) Seawater temperature and sublethal coral bleaching in Jamaica. Coral Reefs 8:193-197

Gates RD, Baghdasarian G, Muscatine L (1992) Temperature stress causes host cell detachment in symbiotic cnidarians: implications for coral bleaching. Bıol Bull (Woods Hole) 182:324-332

Gleason DF, Wellington GM (1993) Ultraviolet radiation and coral bleaching. Nature 365:836-838

Glynn PW (1990) Coral mortality and disturbances to coral reefs in the tropical eastern Pacific. In: Gilynn PW (ed) Global ecological consequences of the 1982-83 El-Ninosouthern oscillation. Elsevier Oceanography Series 52 , Amsterdam, p 55-126

Glynn PW (1991a) Coral reef bleaching in the 1980s and possible connections with global warming. Trends Ecol Evol 6:175-179

Glynn PW (1991b) Elimination of two reef-building hydrocorals following the 1982-83 El-Niño warming event. Science 253:69-71

Glynn PW (1993) Coral reef bleaching: ecological perspectuves. Coral Reefs 12:1-17

Glynn PW, D'Croz L (1990) Experimental evidence for high temperatures stress as the cause of El-Niño-coincident coral mortality. Coral Reefs 8:181-191

Glynn PW, Imal R, Sakaj K, Nakano Y, Yamazato K (1992) Experimental responses of Okinawan (Ryukyu Islands, Japan) reef corals to high sea temperature and UV radıation. Proc 7th Int Coral Reefs Symp, Guam 1:27-37

Glynn PW, Peters EC, Muscatine L (1985) Coral tissue microstructure and necrosis: relation to catastrophic coral mortality in Panama. Dis Aquat Org 1:29-37

Goreau TJ (1990) Coral bleaching in Jamaica. Nature 343:417

Hagman DK, Gittings SR (1992) Coral bleaching on high latutude reefs at the Flower Garden Banks, NW Gulf of Mexico. Proc 7th Int Coral Reefs Symp, Guam 1:38-43

Hayes RL, Bush PG (1990) Microscopic observations of recovery in the reef-building scleractinian coral, Montastrea annularis, after bleaching on a Cayman reef. Coral Reefs 8:203-209

Hoegh-Guldberg O, Salvat B (1995) Periodic mass-bleaching and elevated sea temperatures: bleaching of outer reef slope communities in Moorea, French Polynesia. Mar Ecol Prog Ser 121:181-190

Hoyle BD, Williams LJ, Costerton JW (1993) Production of mucoid exopolysaccharide during development of Pseudomonas aeruginosa biofilms. Infect Immun 61 $777-780$

This article was submitted to the editor
Huang CT, Yu FP, McFeters GA, Stewart PS (1995) Nonuniform spatial patterns of respiratory activity within biofilms during disinfection. Appl Environ Microbiol 61:2252-2256

Jokiel PL, Coles SL (1977) Effects of temperature on the mortality and growth of Hawaiian reef corals. Mar Biol 43: 201-208

Jokiel PL, Coles SL (1990) Response of Hawaiian and other Indo-Pacific reef corals to elevated temperature. Coral Reefs 8:155-162

Kushmaro A, Loya Y, Fine M, Rosenberg E (1996) Bacterial infection and coral bleaching. Nature 380:396

Lang JC, Lasker HR, Gladfelter EH, Hallock P, Jaap WC, Losa F. Muller RG (1992) Spatial and temporal variability during periods of 'recovery' after mass bleaching on Western Atlantic coral reefs. Am Zool 32:696-706

Mitchell R, Chet I (1975) Bacterial attack of corals in polluted seawater. Microb Ecol 2:227-233

Ogden JC, Wicklund RI (1988) Mass bleaching of coral reefs in the Caribbean: a research strategy. NOAA Undersea Res Prog research report $88-250$

Oliver J (1985) Recurrent seasonal bleaching and mortality of corals on the Great Barrier Reef. Proc 5th Int Coral Reefs Symp. Tahiti 4:201-206

Peters EC, Oprandy JJ, Yevich PP (1983) Possible causal agent of 'white band disease' in Caribbean acroporid corals. J Invertebr Pathol 41:394-396

Ritchie KB, Dennis JH, McGrath T, Smith GW (1994) Bacteria associated with bleached and nonbleached areas of Montastrea annularis. In: Kass L (ed) Bahamian field station. Proc 5th Symp Nat Hist Bahamas, San Salvador, Bahamas, p $75-79$

Ritchie KB, Smith GW (1994) Carbon source utilization patterns of coral associated marne heterotrophs. 3rd Int Mar Biotechnol Conf, August 1994, Tromsoe, Norway

Rowan R, Knowlton N (1995) Interspecific diversity and ecological zonation in coral-algal symbiosis. Proc Natl Acad Sci USA 92:2850-2853

Rublee PA, Lasker HR, Gottfried M, Roman MR (1980) Production and bacterial colonization of mucus from the soft coral Briareum abestinum. Bull Mar Sci 30:888-893

Segel LA, Ducklow HW (1982) A theoretical investigation into the influence of sublethal stress on coral bacterial ecosystem dynamics. Bull Mar Sci 32:919-935

Shick JM, Lesser MP, Dunlap WC, Stochaj WR, Chalker BE, Wu Won J (1995) Depth-dependent responses to solar ultraviolet radiation and oxidative stress in the zooxanthellate coral Acropora microphthalma. Mar Biol 122: $41-51$

Smith SV, Buddemeier RW (1992) Global change and coral reef ecosystems. Ann Rev Ecol Syst 23:89-118

Sorokin YI (1973) Trophical role of bacteria in the ecosystem of the coral reef. Nature 242:415-417

Zibrowius H (1974) Oculina patagonica, scleractiniaire hermatypique introduit en Mediterranee. Helgol Meeresunters 26:153

Manuscript first received: August 1, 1996

Revised version accepted: October 25, 1996 